\title{
ASSESSMENT OF SKELETAL FLUOROSIS AMONG CHILDREN IN TWO BLOCKS OF RURAL AREA, JAIPUR DISTRICT, RAJASTHAN, INDIA
}

\author{
CHETRAM MEENA ${ }^{1}$, SUPRIYA DWIVEDI ${ }^{1}$, SUMAN RATHORE ${ }^{1}$, ZAOZIANLUNGLIU GONMEI ${ }^{2}$, TOTEJA GS ${ }^{3 *}$, \\ KUMUD BALA ${ }^{1}$, MOHANTY SS ${ }^{3}$
}

${ }^{1}$ Department of Biotechnology, Amity Institute of Biotechnology, Amity University, Noida - 201 303, Uttar Pradesh, India. ${ }^{2}$ Department of Foods and Nutrition, Amity Institute of Food Technology, Amity University, Noida - 201 303, Uttar Pradesh, India. ${ }^{3}$ Desert Medicine Research Centre, Indian Council of Medical Research, Jodhpur - 342 005, Rajasthan, India. Email: gstoteja@gmail.com

Received: 15 May 2017, Revised and Accepted: 05 June 2017

ABSTRACT

Objective: The objective of the present study was carried out to explore the potential association between fluoride (F) concentration in drinking water and severity of skeletal fluorosis (SF) among the children of rural area.

Methods: SF survey was conducted among the children (6-14 years) in two blocks such as (a) Jamwa Ramgarh block in Heerawala, Palera, Nayabas, Saipur, and Birasana and (b) Amber block in Sunder Ka Bas, Chitanukalan, Jugalpura, Peelwa, and Sirsali in Jaipur district of Rajasthan, India, of the study villages. A total of 150 (93 male and 57 female) children were surveyed. The role of fluoride (F) concentration in drinking water in the etiology of $\mathrm{SF}$ and the cases of SF was assessed using. The United Nations Children's Fund three clinical test. The fluoride content in the source of drinking water was estimated by fluoride ion-specific electrode (Thermo Scientific Orion Star A329, USA).

Results: The fluoride concentration in hand pump $(\mathrm{Hp})$ water which ranges from 2.1 to 15 parts per million (ppm) and tube well (Tw) water ranges from 0.7 to $6.2 \mathrm{ppm}$ in Jamwa Ramgarh block and Amber block, Hp water which ranges from 0.8 to $5.1 \mathrm{ppm}$ and Tw water ranges from 0.8 to $4.8 \mathrm{ppm}$. The prevalence of SF 9 (12\%) in Jamwa Ramgarh block and 6 (8\%) in Amber block out of 75 children were examined in each block. Significantly increase in fluoride level in drinking water is positively correlated with SF.

Conclusion: This study has shown the relation of SF to high fluoride levels in the source of drinking water is a major risk factor for SF among the children. SF is a threat among the children in two blocks of rural area, Jaipur district, Rajasthan.

Keywords: Skeletal fluorosis, United Nations Children's Fund clinical test, F Ion-specific electrode, Jaipur district.

(c) 2017 The Authors. Published by Innovare Academic Sciences Pvt Ltd. This is an open access article under the CC BY license (http://creativecommons. org/licenses/by/4. 0/) DOI: http://dx.doi.org/10.22159/ajpcr.2017.v10i9.19993

\section{INTRODUCTION}

Fluorine is the most electronegative element and widely distributed as fluoride in nature. Drinking water is the major source of fluoride intake by humans [1]. Fluoride can easily cross the cell membrane and is distributed in cardiac and skeletal muscle, liver, skin, and erythrocytes [2,3]. Fluoride (F) is toxic to all the systems and causes oxidative stress in various tissues of the human body [4]. In India, fluorosis (due to consumption of excess fluoride) is the most prevalent endemic disease which coexists in certain regions in the country. Fluorosis is mainly of three types, i.e., dental, skeletal, and non-skeletal fluorosis (NSF). Skeletal fluorosis (SF) is a global disease not new to India, the reason being the shortage of good quality drinking water and consumption of fluoride (F)-enriched water by the people both in urban and rural areas. Fluorides are mainly found in ground water (GW) when derived by the solvent action of water on the rocks and the soil of the earth's crust [5]. The Bureau of Indian Standards has set a 1.0 parts per million (ppm) maximum permissible limit of fluoride in drinking water and when no other source of drinking water available use more than 1.5 ppm [6]. Fluoride (F) enters the human body mainly through water, food, industrial exposure, drugs, cosmetics, etc [7]. Toothpowder and toothpaste are containing $1000 \mathrm{ppm}$ fluorides [8]. The available data suggest that, in India, 15 states are endemic for fluorides ( $F$ level in drinking water $>1.5 \mathrm{ppm}$ ) and about 62 million people in India suffer from dental, skeletal, and NSF. Out of these, 6 million children are below the age of 14 years [9].

$\mathrm{SF}$ is a chronic metabolic bone disease that occurs when excess amounts of $\mathrm{F}$ accumulate in bone tissue. Because bone growth and remodeling occur over a human's lifespan, SF can progressively worsen with overexposure to a high fluoride (F) levels. Hence, many conditions are associated with SF including osteosclerosis, osteomalacia, osteoporosis, and secondary hyperparathyroidism; severity is also varied, ranging from mild joint pain to crippling disabilities and severe bone deformations $[10,11]$. The effects of the higher concentration of $\mathrm{F}$ exposure on rapidly developing bones in young children are not well understood. Fluoride (F) can alter accretion and reabsorption of bone tissue or interrupt the homeostasis of mineral metabolism in bone. Increased metabolic turnover of bone impaired synthesis of bone or fluoride (F) accumulation in the crystal lattice of skeletal tissue. This is very important mechanisms for how fluoride $(\mathrm{F})$ affects bone tissue in rapidly growing children $[12,13]$.

All the 33 districts in Rajasthan are endemic for fluorides [14]. A higher level of fluoride $(F)$ in source of drinking water was also found in rural areas of Northern Rajasthan. Fluorosis has been appeared as a very serious problem in this region [15]. Very little research studies have been published in the field of SF. In the present study, an attempt was made to understand the relationship between $\mathrm{F}$ in sources of drinking water and severity of SF. Hence, the objective of the present study was to assess the SF among the children in two blocks of rural area, Jaipur district, Rajasthan, India.

\section{METHODS}

Study areas

The study was conducted in the two blocks of rural area such as (a) Jamwa Ramgarh block in Heerawala, Palera, Nayabas, Saipur, and 
Birasana and (b) Amber block in Chitanukalan, Sunder Ka Bas, Jugalpura, Peelwa, and Sirsali in Jaipur district, Rajasthan, India with more than $1.5 \mathrm{ppm}$ concentration of fluoride in source of drinking water, respectively (Public Health and Engineering Department, Government of Rajasthan, Jaipur, and Ministry of Drinking Water and Sanitation, Government of India).

A total of 150 (93 male and 57 female) children (6-14 years old) exhibiting SF-consuming fluoride-contaminated water in endemic fluorosis areas of two blocks of rural area, Jaipur district, Rajasthan, India, were selected through a village-level survey was conducted to assess the SF among the children. After obtaining an informed written consent in local language, the data were recorded in a pretested, semistructured, validated questionnaire consisting of the sociodemographic profile and few questions on sources of drinking water, types of food consumed, and use of fluoride-containing products.

All children were examined for SF by The United Nations Children's Fund clinical test: Three simple clinical tests [16].

1. Coin test: The participants were asked to lift the coin from the floor without bending the knee. A fluorotic participant was not able to lift the coin without flexing the large joints of the lower extremity

2. Chin test: The participants were asked to touch the anterior wall of the chest with the chin. Participants who were unable to perform due to pain or stiffness in the neck; it indicates the presence of fluorosis

3. Stretch test: The participants were asked to stretch the arm sideways, fold at elbow, and touch the back of the head. Participants who were unable to perform due to pain and stiffness, it indicates the presence of fluorosis.

\section{Collection of water sample and analysis}

Source of drinking water from (hand pump [Hp] and tube well [Tw]) was collected in plastic tubes (Tarsons, India) and fluoride (F) concentration in drinking water was estimated with the help of an F ion specific electrode (Thermo Scientific Orion Star A329, USA) using the method of Hall et al. [17]. Detail methodology was described in our earlier communication.

\section{Ethical clearance}

Protocol for this study was approved by the Institutional Ethical Committee of Desert Medicine Research Centre (DMRC), Jodhpur, Rajasthan, India. Informed written consent was obtained from each participant or their parents or legal guardians.

\section{RESULTS}

Fluorosis is a major public health problem in India as well as in Rajasthan. Study area is Jaipur district of Rajasthan, India. Male and female children age from 6-14 years old was selected for the study.

\section{DISCUSSION}

A total of 150 (93 male and 57 female) children were involved from the two blocks of rural area, Jaipur district, Rajasthan. Each block was divided into five villages. A total of ten villages were involved in the study. From each village, 15 children were involved in this study protocol. Village-wise household survey was also carried out for estimate the fluoride content in the source of drinking water in the both block of rural area, Jaipur district, Rajasthan. A higher amount of the $\mathrm{F}$ content was found in Birasana village, Hp water which ranges from 8.5-15 ppm, Tw water (2.5-6.2) followed by Saipur Hp (9.50 ppm), Tw (2.2-4.8), Palera Hp (2.6 ppm), Tw (1.0-2.8 ppm), Heerawala Hp (2.1 ppm), Tw (0.8-2.7 ppm), and Nayabas Tw (0.7$2.10 \mathrm{ppm}$ ) in Jamwa Ramgarh block of the Jaipur district, Rajasthan in Table 1. Village-wise household survey was also carried out in an Amber block of Jaipur district to estimate the fluoride content in the source of drinking water. A higher amount of the fluoride content was found in Sirsali village, Hp water which is $5.1 \mathrm{ppm}$, Tw (2.2-4.8 ppm), followed by Peelwa Hp (2.5 ppm), Tw (0.8-3.5 ppm), Sunder Ka Bas Tw (0.9-2.5 ppm), Jugalpura Hp (0.8 ppm), Tw (2.0-2.5 ppm), and
Chitanukalan Hp (2.0 ppm), Tw (1.4-2.2 ppm) in Amber block of the Jaipur district, Rajasthan in Table 2.

SF cases are higher in Birasana village. Fluorotic children were showed clinical signs and symptoms in Fig. 1. Pain in major joints (5), cannot touch chin with chest (5), cannot bending forward and touch the feet (4), cannot stretch the arms sideways and touch the back of head (4) followed by Saipur, pain in major joints (3), cannot touch chin with chest (1), cannot Bending forward and touch the feet (3), cannot stretch the arms sideways and touch the back of head (3), Palera pain in major joints (1), cannot touch chin with chest (1), cannot stretch the arms sideways and touch the back of head (1) in Jamwa Ramgarh block of Jaipur district, Rajasthan in Table 3. In Amber block, SF cases are high in Sirsali village. A fluorotic children were showed clinical signs and symptoms such as pain in major joints (3), cannot touch chin with chest (3), cannot bending forward and touch the feet (3), cannot stretch the arms sideways and touch the back of head (3) followed by Peelwa, pain in major joints (2), cannot touch chin with chest (2), cannot bending forward and touch the feet (1), cannot stretch the arms sideways and touch the back of head (2), Sunder Ka Bas pain in major joints (1), cannot touch chin with chest (1), cannot stretch the arms sideways and touch the back of head (1) in Amber block of the Jaipur district, Rajasthan in Table 4. No case of SF was found in Heerawala, Nayabas in Jamwa Ramgarh block and Chitanukalan, Jugalpura in Amber block of the Jaipur district, Rajasthan in Tables 3 and 4.
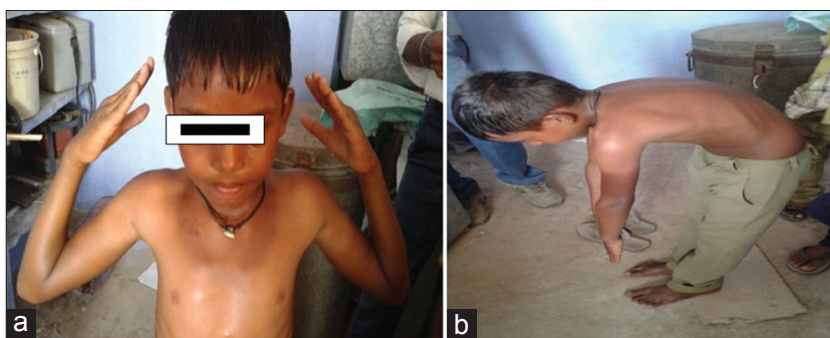

Fig. 1: Skeletal fluorosis: (a) Stretch test, (b) coin test

Table 1: Fluoride concentration in drinking water sources of the selected five villages District: Jaipur 1. Block: Jamwa Ramgarh

\begin{tabular}{|c|c|c|c|c|c|c|}
\hline \multirow[t]{3}{*}{ S. No. } & \multirow[t]{3}{*}{ Name of village } & \multicolumn{5}{|c|}{$\begin{array}{l}\text { Fluoride concentration in } \\
\text { drinking water sources (ppm) }\end{array}$} \\
\hline & & \multicolumn{2}{|l|}{ Нp } & \multicolumn{3}{|l|}{ Tw } \\
\hline & & 1 & 2 & 1 & 2 & 3 \\
\hline 1 & Nayabas & - & - & 1.9 & 0.7 & 2.1 \\
\hline 2 & Heerawala & 2.1 & - & 0.8 & 2.7 & - \\
\hline 3 & Paleda & 2.6 & - & 1.0 & 2.8 & - \\
\hline 4 & Saipur & 9.5 & - & 4.8 & 4.5 & 2.2 \\
\hline 5 & Birasana & 8.5 & 15.0 & 6.2 & 2.5 & - \\
\hline
\end{tabular}

HP: Hand pump, TW: Tube well, ppm: Parts per million

Table 2: Fluoride concentration in drinking water sources of the selected five villages District: Jaipur 2. Block: Amber

\begin{tabular}{|c|c|c|c|c|c|}
\hline \multirow[t]{3}{*}{ S. No. } & \multirow[t]{3}{*}{ Name of village } & \multicolumn{4}{|c|}{$\begin{array}{l}\text { Fluoride concentration in } \\
\text { drinking water sources (ppm) }\end{array}$} \\
\hline & & \multirow[t]{2}{*}{ Hp } & \multicolumn{3}{|l|}{ Tw } \\
\hline & & & 1 & 2 & 3 \\
\hline 1 & Chitanu Kalan & 2.0 & 1.4 & 2.2 & - \\
\hline 2 & Jugalpura & 0.8 & 2.0 & 2.5 & - \\
\hline 3 & Sunder Ka Bas & - & 2.5 & 0.9 & 2.3 \\
\hline 4 & Peelwa & 2.5 & 0.8 & 3.5 & - \\
\hline 5 & Sirsali & 5.1 & 4.8 & 3.5 & 2.2 \\
\hline
\end{tabular}

HP: Hand pump, TW: Tube well, ppm: Parts per million 
The fluoride (F) concentration in sources of drinking water ( $\mathrm{Hp}$ and $\mathrm{Tw}$ ) was ranged from 2.1 to $15 \mathrm{ppm}$ and 0.7 to $6.2 \mathrm{ppm}$ in Jamwa Ramgarh block and Amber block (Hp and Tw water) were ranged from 0.8 to 5.1 ppm and 0.8 to $4.8 \mathrm{ppm}$ in Jaipur district, Rajasthan. Both in Tables 1 and 2, data show that the F concentration in $\mathrm{Hp}$ water was found more as compare to Tw water sources. World Health Organization was prescribed the maximum permissible limits of $1.5 \mathrm{ppm}$ fluoride (F) concentration in drinking water [18]. This indicates that the occurrence of fluorosis in an area can be affected by a number of other factors such as nutritional status, difference in lifestyles, altitude, climate, individual susceptibility and biological response, duration of fluoride exposure, and dissolved salts in drinking water [19]. Organic and inorganic pollutants in ground water are hazardous for human health [20]. In Rajasthan, indigenous rocks are a rich source of fluoride in drinking water and ground water around the mica mines as Rajasthan has rich sources of mica.

The prevalence of SF can be estimated using clinical symptoms and ability to do physical exercises as developed [21] and used by [22]. The prevalence of SF 9 (12\%) in Jamwa Ramgarh block and $6(8 \%)$ in Amber block out of 75 children were examined in each block has shown in Tables 3 and 4. In India, SF was also found in the children with low prevalence (5.2\%) but at high F concentrations ( $4.8 \mathrm{ppm}$ ) in drinking water [23]. The prevalence of SF manifestations was found to be $6.6-26.2 \%$ in a study was conducted in two fluoroses (F) endemic blocks of West Bengal, India [24]. Similar to the present study findings, adults and male participants were shown $18.46 \%$ prevalence of SF in Agra district [25]. Severe bone deformities in endemic fluorosis have also been identified among the children who live in India. In a recent study, signs of SF including Genu valgum, Genu varum, and anterior bowing of legs were identified in children aged 1-18 years, who resided in endemic fluorosis villages of the Bihar State, India. Study investigators concluded that high rates of SF among children in this region are due to overexposure to high fluoride (F) levels coupled with serious vitamin and mineral deficiencies, especially calcium and Vitamin D deficiencies [12]. In this study, we were not able to conclude whether the vitamin and mineral intake among the children. It is possible that the severity of SF cases among the children in Jamwa Ramgarh and Amber block of Jaipur district, Rajasthan may vary due to other factors that could include the children diet and intake of vitamins and minerals necessary for proper bone growth and development. Further investigation is necessary to assess all the potential factors that contribute to SF incidence and severity among children. In the present investigation, in summary, as well as the water fluoride (F) levels being positively correlated with the severity of SF among the children. However, due to the many limitations in this study, more research with larger sample sizes is needed to arrive at any conclusion.

\section{CONCLUSION}

Our data show the prevalence of SF 9 (12\%) in Jamwa Ramgarh block and $6(8 \%)$ in Amber block among the children of Jaipur district. A higher F level in source of drinking water is a major risk factor for SF. This study is important as it can be providing baseline information and data about SF to public health authorities to control fluoride content in drinking water sources by establishing defluoridation unit and also provide proper health education, dietary practice of calcium and magnesiumrich cereals, vegetables, dairy products, and the use of rainwater for household consumption and preparation of food might help in reducing risk of fluorosis and intervention study may be planned in the future to control the fluorosis problem among the children of rural area, Jaipur district, Rajasthan, India.

\section{ACKNOWLEDGMENT}

I wish to express my sincere gratitude to my research supervisor Dr. G. S. Toteja, Director, DMRC c/o Model Rural Health Research Unit, Department of Health Research, Ministry of Health and Family Welfare, Government of India, Bhanpur kalan, Jaipur, Rajasthan, for providing necessary support, guidance, and encouragement.

Table 3: Clinical signs and symptoms of skeletal fluorosis among children of Jaipur district: 1. Block: Jamwa Ramgarh

\begin{tabular}{|c|c|c|c|c|c|c|c|c|c|}
\hline \multirow[t]{2}{*}{ S. No. } & \multirow{2}{*}{$\begin{array}{l}\text { Name of } \\
\text { village }\end{array}$} & \multirow{2}{*}{$\begin{array}{l}\text { Number of } \\
\text { children } \\
\text { examined } \\
\text { Age (6-14 years) }\end{array}$} & \multirow{2}{*}{$\begin{array}{l}\text { Male } \\
\text { children }\end{array}$} & \multirow{2}{*}{$\begin{array}{l}\text { Female } \\
\text { children }\end{array}$} & \multicolumn{4}{|c|}{ Clinical signs and symptoms of SF } & \multirow{2}{*}{$\begin{array}{l}\text { Prevalence } \\
\text { of SF in } \\
\text { children (\%) }\end{array}$} \\
\hline & & & & & $\begin{array}{l}\text { Pain in } \\
\text { major } \\
\text { joints }\end{array}$ & $\begin{array}{l}\text { Cannot } \\
\text { touch chest } \\
\text { with chin }\end{array}$ & $\begin{array}{l}\text { Cannot bending } \\
\text { forward and } \\
\text { touch the feet }\end{array}$ & $\begin{array}{l}\text { Cannot stretch } \\
\text { the arms } \\
\text { sideways and } \\
\text { touch the back } \\
\text { of head }\end{array}$ & \\
\hline 1 & Paleda & 15 & 5 & 10 & 1 & 1 & - & 1 & $1(6.6)$ \\
\hline 3 & Nayabas & 15 & 11 & 4 & - & - & - & - & 0 \\
\hline 4 & Saipur & 15 & 7 & 8 & 3 & 1 & 3 & 3 & $3(20)$ \\
\hline 5 & Birasana & 15 & 5 & 10 & 5 & 5 & 4 & 4 & $5(33.3)$ \\
\hline Total & & 75 & 40 & 35 & 9 & 7 & 7 & 8 & $9(12)$ \\
\hline
\end{tabular}

SF: Skeletal fluorosis

Table 4: Clinical signs and symptoms of skeletal fluorosis among children of Jaipur district: 2. Block: Amber

\begin{tabular}{|c|c|c|c|c|c|c|c|c|c|}
\hline \multirow[t]{2}{*}{ S. No. } & \multirow{2}{*}{$\begin{array}{l}\text { Name of } \\
\text { village }\end{array}$} & \multirow{2}{*}{$\begin{array}{l}\text { Number of } \\
\text { children } \\
\text { examined } \\
\text { Age } \\
\text { (6-14 years) }\end{array}$} & \multirow{2}{*}{$\begin{array}{l}\text { Male } \\
\text { children }\end{array}$} & \multirow{2}{*}{$\begin{array}{l}\text { Female } \\
\text { children }\end{array}$} & \multicolumn{4}{|c|}{ Clinical signs and symptoms of SF } & \multirow{2}{*}{$\begin{array}{l}\text { Prevalence } \\
\text { of SF in } \\
\text { children (\%) }\end{array}$} \\
\hline & & & & & $\begin{array}{l}\text { Pain in } \\
\text { major } \\
\text { joints }\end{array}$ & $\begin{array}{l}\text { Cannot } \\
\text { touch chest } \\
\text { with chin }\end{array}$ & $\begin{array}{l}\text { Cannot bending } \\
\text { forward and } \\
\text { touch the feet }\end{array}$ & $\begin{array}{l}\text { Cannot stretch } \\
\text { the arms } \\
\text { sideways and } \\
\text { touch the back } \\
\text { of head }\end{array}$ & \\
\hline 1 & Chitanu Kalan & 15 & 12 & 3 & - & - & - & - & 0 \\
\hline 3 & Sunder Ka Bas & 15 & 8 & 7 & 1 & 1 & - & 1 & $1(6.6)$ \\
\hline 4 & Peelwa & 15 & 12 & 3 & 2 & 2 & 1 & 2 & $2(13.3)$ \\
\hline 5 & Sirsali & 15 & 11 & 4 & 3 & 3 & 3 & 3 & $3(20)$ \\
\hline Total & & 75 & 53 & 22 & 6 & 6 & 4 & 6 & $6(8)$ \\
\hline
\end{tabular}

SF: Skeletal fluorosis 


\section{REFERENCES}

1. WHO. Environmental Health Criteria for Fluorine and Fluorides. Geneva: World Health Organization; 1984. p. 1-136.

2. Carlson CH, Armstrong WD, Singer L. Distribution and excretion of radio-fluoride in the human. Proc Soc Exp Biol Med 1960;104:235-9.

3. Jacyszyn K, Marut A. Fluoride in blood and urine in humans administered fluoride and exposed to fluoride-polluted air. Fluorid 1986;19(1):26-32.

4. Vasant RA, Narasimhacharya AV. Alleviatory effects of (Emblica officinalis $\mathrm{G}$ ). As a food supplement in fluoride induced hyperlipemia and oxidative stress. Int J Pharm Pharm Sci 2012;4(1):404-8.

5. Wedepohl KH. Hand Book of Geochemistry. Vol. 2. Berlin, Heidelberg, New York: Springer Verlag; 1974. p. 9k-1.

6. BIS. Draft Indian Standard Drinking Water Specification (First Revision of IS 10500). Bureau of Indian Standards (BIS), New Delhi; 1991.

7. Sarala K, Rao PR. Endemic fluorosis in the village Ralla Anantapuram in Andhra Pradesh - An epidemiological study. Fluorid 1993;26:177-80.

8. Deshpande RR, Kachare P, Sharangpani G, Varghese VK, Bahulkar NS. Comparative evaluation of antimicrobial efficacy of two commercially available dentifrices (fluoridated and herbal) against salivary microflora. Int J Pharm Pharm Sci 2014;6(6):72-4.

9. Susheela AK. Fluorosis Indian Scenario: A Treatise on Fluorosis. New Delhi, India: Fluorosis Research and Rural Development Foundation; 2001.

10. Singh A, Jolly SS. Chronic toxic effects on the skeletal system. In: Fluorides and Human Health. Vol. 59. Geneva, Switzerland: WHO; 1970. p. 238-49.

11. Wang Y, Yin Y, Gilula LA, Wilson AJ. Endemic fluorosis of the skeleton: Radiographic features in 127 patients. Am J Roentgenol 1994;162(1):93-8.

12. Khandare L, Harikumar R, Sivakumar B. Severe bone deformities in young children from vitamin D deficiency and fluorosis in Bihar-India. Calcif Tissue Int 2005;76(6):412-8.

13. Zhang H, Cai Q, Fang S. Study on epidemic factors of skeletal fluorosis in children and adolescents in Guizhou Province. Chin J Epidemiol
1997;16(1):1-4.

14. Yadav JP, Lata S, Kataria SK, Kumar S. Fluoride distribution in ground water and survey of dental fluorosis among school children in the villages of the Jhajjar district of Haryana, India. Environ Geochem Health 2009;31(4):431-8.

15. Suthar S, Garg VK, Jangir S, Kaur S, Goswami N, Singh S. Fluoride concentration in drinking water in rural habitations of Northern Rajasthan, India. Environ Monit Assess 2008;145(1-3):1-6.

16. Susheela AK. Epidemiological studies of health risks from drinking water naturally contaminated with fluoride. In: Reichard EG, Zapponi GA, editors. Assessing and Managing Health Risks from Drinking Water Contamination: Approaches and Applications. Wallingford-Oxfordshire, UK: IAHS Press; 1995.

17. Hall LL, Smith F, Hodge HC. Direct determination of ionic fluoride in biological fluids. Clin Chem 1972;18(12):1455-8

18. WHO: Guideline for Drinking-Water Quality. $3^{\text {rd }}$ ed., Vol. 1. Geneva, Switzerland: World Health Organization; 2004. p. 516.

19. Choubisa SL. Endemic fluorosis in Southern Rajasthan, India. Fluorid 2001;34(1):61-70

20. Shah B, Pandya D, Patel H, Ayalew A, Shah A. Zeolitic composites from agricultural detritus for pollution remedy: A review. J Crit Rev 2016;3(3):41-9.

21. Susheela AK, Bhatnagar M. Reversal of fluoride induced cell injury through elimination of fluoride and consumption of diet rich in essential nutrients and antioxidants. Mol Cell Biochem 2002;234235(1-2):335-40.

22. Shashi A, Kumar M, Bhardwaj M. Incidence of skeletal deformities in endemic fluorosis. Trop Doct 2008;38:231-3.

23. Choubisa SL, Choubisa L, Choubisa DK. Endemic fluorosis in Rajasthan. Indian J Environ Health 2001;43(4):177-89.

24. Majumdar KK. Prevalence of fluorosis and pattern of domestic filters use in two fluoride endemic blocks of West Bengal, India. J Compr Health 2015;3:1730.

25. Garg S. Prevalence of fluorosis among children and adults. Int J Pharm Res Innov 2011;4:25-31. 